\title{
Removal of Uranium from Plutonium Solutions by Anion Exchange
}

\section{Tracy S. Rudisill and Jonathan M. Duffey}

February 2002

Westinghouse Savannah River Company Aiken, SC 29808 
This document was prepared in conjunction with work accomplished under Contract No. DEAC09-96SR18500 with the U.S. Department of Energy.

\section{DISCLAIMER}

This report was prepared as an account of work sponsored by an agency of the United States Government. Neither the United States Government nor any agency thereof, nor any of their employees, makes any warranty, express or implied, or assumes any legal liability or responsibility for the accuracy, completeness, or usefulness of any information, apparatus, product or process disclosed, or represents that its use would not infringe privately owned rights. Reference herein to any specific commercial product, process or service by trade name, trademark, manufacturer, or otherwise does not necessarily constitute or imply its endorsement, recommendation, or favoring by the United States Government or any agency thereof. The views and opinions of authors expressed herein do not necessarily state or reflect those of the United States Government or any agency thereof.

This report has been reproduced directly from the best available copy.

Available for sale to the public, in paper, from: U.S. Department of Commerce, National Technical Information Service, 5285 Port Royal Road, Springfield, VA 22161

phone: (800) 553-6847

fax: (703) 605-6900

email: orders@ntis.fedworld.gov

online ordering: http://www.ntis.gov/support/index.html

Available electronically at http://www.osti.gov/bridge

Available for a processing fee to U.S. Department of Energy and its contractors, in paper, from: U.S. Department of Energy, Office of Scientific and Technical Information, P.O. Box 62, Oak Ridge, TN 37831-0062

phone: (865)576-8401

fax: (865)576-5728

email: reports@adonis.osti.gov 


\section{Removal of Uranium from Plutonium Solutions by Anion Exchange}

$$
\text { By }
$$

Tracy S. Rudisill and Jonathan M. Duffey

Issued: February 2002

\section{Approvals}

Tracy S. Rudisill, Author

Date

Jonathan M. Duffey, Author

Date

Allen L. Blancett, Manager / Actinide Technology Section

Date

Neal M. Askew, Technical Reviewer

Date

Robert H. Smith Jr., Technical Reviewer

Date 


\section{This page was intentionally left blank.}


Revision 0

\section{Table of Contents}

\section{Section}

Page

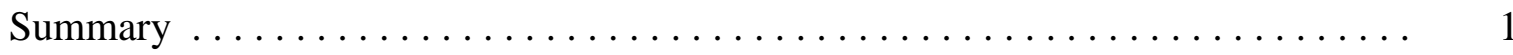

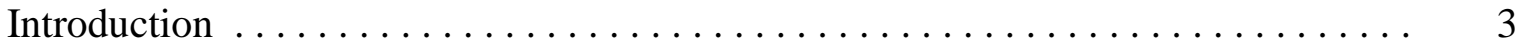

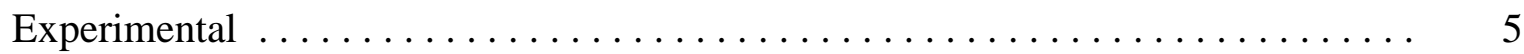

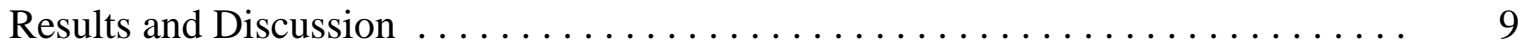

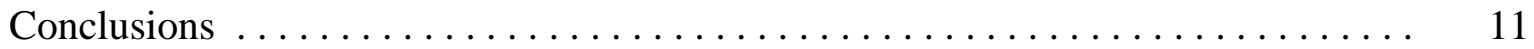

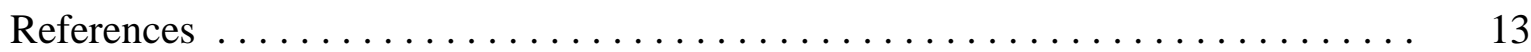




\section{List of Tables}

Page

Table 1 Comparison of HB-Line and Laboratory-scale Column $\ldots \ldots \ldots$ Geometry

Table 2 Anion Exchange Column Operating Conditions $\ldots \ldots \ldots \ldots \ldots$

Table 3 Composition of Feed Solutions for Anion Exchange . . . . . . . . 6 Experiments

Table 4 Washing Requirements to Purify a $1 \mathrm{~kg}$ Batch of Plutonium . . . . . 10

\section{List of Figures}

Figure $1 \quad$ Uranium Concentration in Effluent Streams During . . . . . . . . 15 Anion Exchange Column Operation

Figure 2 Cumulative Recovery of Uranium in Effluent Streams . . . . . . 17 During Anion Exchange Column Operation

Figure 3 Estimated Washing Requirements to Achieve . . . . . . . . . . 19 $\leq 0.01 \mathrm{~g}$ Uranium/g Plutonium in Column Product Stream

\section{List of Appendices}

Appendix A Analytical Results from Anion Exchange Experiments . . . . . . . 21

Appendix B Material Balances for Anion Exchange Experiments . . . . . . . . 25 


\title{
Removal of Uranium from Plutonium Solutions by Anion Exchange
}

\author{
Tracy S. Rudisill and Jonathan M. Duffey \\ Westinghouse Savannah River Company \\ Savannah River Site \\ Aiken, SC 29808
}

\section{Summary}

The anion exchange capacity in the HB-Line Phase II Facility will be used to purify plutonium solutions potentially containing significant quantities of depleted uranium. Following purification, the plutonium will be precipitated as an oxalate and calcined to plutonium oxide $\left(\mathrm{PuO}_{2}\right)$ for storage until final disposition. A uranium to plutonium ratio in the feed to the precipitation process $\leq 0.01 \mathrm{~g} / \mathrm{g}$ is desired to ensure that the mass loss associated with the conversion of any uranium trioxide (produced during calcination) to compounds with higher uranium to oxygen ratios does not bias the loss-on-ignition test required for storage. Removal of the uranium prior to precipitation can be accomplished by washing the plutonium loaded onto the resin during anion exchange. To quantify the washing requirements to achieve the desired plutonium purification, two anion exchange experiments were performed to measure plutonium decontamination as a function of the volume of wash solution. The initial column run was performed using a feed solution containing a worst case uranium to plutonium mass ratio of nominally $3: 1$. In the second experiment, an almost identical feed solution prepared without plutonium was loaded onto the resin to maximize uranium loading, and the subsequent washing requirements to achieve the desired plutonium/uranium separation were determined.

The effect of the volume of wash solution on the purity of the plutonium product produced during the anion exchange experiments was determined by periodically measuring the uranium concentration in the effluent streams. By calculating the cumulative removal of uranium during column operations, the required number of bed volumes of wash solution to achieve the desired plutonium/uranium separation can be predicted for any uranium to plutonium ratio. The effect of increased uranium loading when plutonium was not present in the feed solution was clearly seen when the concentration profiles of the effluent streams and the cumulative uranium removal from the column were compared for the two experiments. However, the additional volume of wash solution required to achieve the same plutonium decontamination was not excessive; only 1-2 additional bed volumes were required. The number of bed volumes of wash solution predicted by the data does not take into account the potential for holdup of solution in the HB-Line piping. Additional wash solution would be required to flush any uranium from the process lines upstream from the columns. 


\section{This page was intentionally left blank.}




\section{Introduction}

The anion exchange capacity in the HB-Line Phase II Facility will be used to purify plutonium solutions presently stored in H-Canyon and additional solutions from the dissolution of plutonium-containing scrap in the Phase I Facility. The plutonium will then be precipitated as an oxalate and calcined to an oxide $\left(\mathrm{PuO}_{2}\right)$ in subsequent processing operations. Some of the plutonium solutions and materials to be dissolved in the Phase I Facility contain significant quantities of depleted uranium which must be removed during purification. A uranium to plutonium ratio in the feed to the precipitation process of $\leq 0.01 \mathrm{~g} / \mathrm{g}$ is desired to ensure that the conversion of any uranium trioxide $\left(\mathrm{UO}_{3}\right)$ (produced during calcination) to compounds with higher uranium to oxygen ratios (i.e. $\mathrm{U}_{3} \mathrm{O}_{8}$ ) will not bias loss-on-ignition tests. A loss-onignition test (or an equivalent measure of moisture content) is required to meet criteria established for the long-term storage of plutonium [1]. The storage standard requires heating a sample of the $\mathrm{PuO}_{2}$ in air to a temperature of $1000^{\circ} \mathrm{C}$ for at least $1 \mathrm{~h}$ to measure any change in mass due to residual volatile species. If the $\mathrm{PuO}_{2}$ contains a significant quantity of $\mathrm{UO}_{3}$, the conversion to $\mathrm{U}_{3} \mathrm{O}_{8}$ (see equation (1)) would result in a decrease in mass not attributed to water or another volatile species.

$$
3 \mathrm{UO}_{3} \rightarrow \mathrm{U}_{3} \mathrm{O}_{8}+1 / 2 \mathrm{O}_{2}
$$

Removal of significant uranium contamination from the plutonium solutions processed in the HB-Line Phase II Facility can be accomplished by anion exchange. Once loaded onto the resin, the plutonium can be decontaminated from uranium by washing with 7-8M nitric acid solution. The distribution coefficient $\left(\mathrm{D}_{\mathrm{v}}\right)$ for uranium in a nitrate anion exchange column is $\sim 4$ compared to a $D_{v}$ of $\sim 1000$ for plutonium.[2] The large difference in the $D_{v}$ 's is due to the formation of the plutonium hexanitrato anion $\left(\mathrm{Pu}\left(\mathrm{NO}_{3}\right)_{6}{ }^{2-}\right)$ which is strongly adsorbed on the resin compared to uranium (VI) $\left(\mathrm{UO}_{2}{ }^{2+}\right)$ complexes. In pure nitric acid solution, $\mathrm{UO}_{2}{ }^{2-}$ only forms small equilibrium concentrations of the tetranitrato $\left(\mathrm{UO}_{2}\left(\mathrm{NO}_{3}\right)_{4}{ }^{2-}\right)$ and trinitrato $\left(\mathrm{UO}_{2}\left(\mathrm{NO}_{3}\right)_{3}{ }^{-}\right)$anions which are adsorbed on the resin.[3] The low affinity uranium has for the resin compared to plutonium can be used to achieve a very high degree of purification as the number of bed volumes of wash solution increases.

To quantify the necessary washing requirements to achieve the desired plutonium purification, two anion exchange experiments were performed to measure plutonium decontamination as a function of the number of bed volumes of wash solution. Initially, an experiment was performed using a feed solution containing a worst case uranium to plutonium mass ratio of nominally 3:1. Following the first column run, a decision was made to perform an additional experiment to measure the effect of decreasing plutonium concentration on the amount of uranium which can be removed during column washing. Since plutonium adsorption on the resin is much stronger than uranium, decreasing the plutonium concentration will free additional capacity for uranium adsorption. Therefore, uranium removal would decrease with decreasing plutonium concentration. To investigate this effect, the second column experiment was performed using the same operating conditions as the initial experiment, but no plutonium was added to the feed solution. Performing the experiment in this manner maximized the amount of uranium which loaded onto the resin. 


\section{This page was intentionally left blank.}




\section{Experimental}

\section{$\underline{\text { Laboratory-Scale Column and Operating Conditions }}$}

A $1.9 \mathrm{~cm}$ (0.75 in) ID column with a $68.6 \mathrm{~cm}$ (27 in) resin height was used to perform the anion exchange column runs. The height of the resin in the column was equivalent to the resin height in the HB-Line Phase II columns. The amount of plutonium in the feed solution for the initial experiment was scaled based on the cross sectional areas of the laboratory and HB-Line columns. The plutonium batch sizes and the column geometry are compared in Table 1 .

Table 1 Comparison of HB-Line and Laboratory-Scale Column Geometry

\begin{tabular}{lcc}
\hline \hline Column Parameter & HB-Line & Laboratory-Scale \\
\hline Plutonium Batch Size $(\mathrm{g})$ & 1000 & 9.6 \\
Diameter $(\mathrm{cm} / \mathrm{in})$ & $19.4 / 7.62$ & $1.9 / 0.75$ \\
Cross Sectional Area $\left(\mathrm{cm}^{2}\right)$ & 294 & 2.84 \\
Resin Height $(\mathrm{cm} / \mathrm{in})$ & $68.6 / 27$ & $68.6 / 27$ \\
Bed Volume $(\mathrm{mL})$ & 20177 & 194 \\
\hline
\end{tabular}

The flow rates for column conditioning, washing, and elution were also scaled using the ratio of column cross sectional areas. The flow rate for column loading was based on work by Kyser [4] in which the plutonium loading capacity of Reillex $\mathrm{HPQ}^{\mathrm{TM}}$ resin was measured using a mass flux of $16-17 \mathrm{mg}$ plutonium/min- $\mathrm{cm}^{2}$. The volume of feed solution for each experiment was constrained to $3.5 \mathrm{~L}$ due to the difficulty in managing large volumes of solution in a laboratory glovebox. The volume of solution for column washing was established as nominally 20 bed volumes for each experiment. The column operating conditions for the experiments and basis from which they were derived are summarized in Table 2.

Table 2 Anion Exchange Column Operating Conditions

\begin{tabular}{lcccc}
\hline \hline \multicolumn{1}{c}{$\begin{array}{c}\text { Column } \\
\text { Operation }\end{array}$} & $\begin{array}{c}\text { HB-Line } \\
\text { Volume } \\
(\mathrm{L})\end{array}$ & $\begin{array}{c}\text { Laboratory-Scale } \\
\text { Volume } \\
(\mathrm{L})\end{array}$ & $\begin{array}{c}\text { HB-Line } \\
\text { Flowrate } \\
(\mathrm{mL} / \mathrm{min})\end{array}$ & $\begin{array}{c}\text { Laboratory-Scale } \\
\text { Flowrate } \\
\text { mL/min) }\end{array}$ \\
\hline Conditioning & 30 & 289 & 2.0 & 19 \\
Feed & N/A & $3500^{(1)}$ & N/A & $18^{(3)}$ \\
Wash & N/A & $3889^{(2)}$ & 2.7 & 26 \\
Elution & 60 & 578 & 0.7 & 7 \\
\hline
\end{tabular}

(1) Constrained by available glovebox space

(2) 20 column bed volumes of solution

(3) Based on a plutonium mass flux of $17 \mathrm{mg} / \mathrm{min}-\mathrm{cm}^{2}$

\section{Anion Exchange Resin}

The plutonium decontamination experiments were performed with Reillex $\mathrm{HPQ}^{\mathrm{TM}}$ anion exchange resin obtained from Reilly Industries Inc. (lot no. 8030ZMA). Initially the resin was 
converted from the chloride to the nitrate form by contacting with 10 bed volumes (approximately $2 \mathrm{~L}$ ) of $1 \mathrm{M}$ sodium nitrate.

\section{$\underline{\text { Preparation of Feed Solutions }}$}

The feed solution for the first experiment was prepared using a worst case uranium to plutonium mass ratio of nominally $3: 1$. Therefore, approximately $29 \mathrm{~g}$ of uranium were required to prepare a solution containing $9.6 \mathrm{~g}$ of plutonium. Initially $70 \mathrm{~g}$ of reagent grade uranyl nitrate hexahydrate (UNH) were transferred to a plastic bottle containing $500 \mathrm{~mL}$ of $8 \mathrm{M}$ nitric acid. The resulting solution was nominally $66 \mathrm{~g} / \mathrm{L}$ uranium. The $9.6 \mathrm{~g}$ of plutonium were obtained from a $40 \mathrm{~g} / \mathrm{L}$ plutonium solution previously purified by anion exchange. The free acid concentration of the solution was approximately $0.7 \mathrm{M}$. The final feed solution was prepared by combining $244 \mathrm{~mL}$ of the plutonium stock solution, the $66 \mathrm{~g} / \mathrm{L}$ uranium solution, and the required amounts of concentrated $(15.7 \mathrm{M})$ nitric acid and deionized water required to obtain $3500 \mathrm{~mL}$ of solution containing $8 \mathrm{M}$ nitric acid. The final composition of the feed solution for the first experiment is given in Table 3.

Table 3 Composition of Feed Solutions for Anion Exchange Experiments

\begin{tabular}{|c|c|c|c|c|c|}
\hline \multirow{2}{*}{$\begin{array}{c}\text { Experiment } \\
\text { No. }\end{array}$} & \multicolumn{2}{|r|}{ Uranium } & \multicolumn{2}{|c|}{ Plutonium } & \multirow{2}{*}{$\begin{array}{l}\text { Nitric Acid } \\
\text { Concentration } \\
(\mathrm{M})\end{array}$} \\
\hline & $\begin{array}{l}\text { Mass } \\
(\mathrm{g})\end{array}$ & $\begin{array}{c}\text { Concentration } \\
(\mathrm{g} / \mathrm{L})\end{array}$ & $\begin{array}{c}\text { Mass } \\
(\mathrm{g})\end{array}$ & $\begin{array}{c}\text { Concentration } \\
(\mathrm{g} / \mathrm{L})\end{array}$ & \\
\hline $1^{(1)}$ & 33.2 & 9.5 & 9.6 & 2.8 & 8.0 \\
\hline 2 & 33.2 & 9.5 & & & 8.0 \\
\hline
\end{tabular}

(1) Plutonium to uranium ratio of $3.4: 1$

The feed solution for the second anion exchange experiment was prepared in the same manner as noted above. Nominally $70 \mathrm{~g}$ of UNH were transferred to a bottle containing $500 \mathrm{~mL}$ of $8 \mathrm{M}$ nitric acid. The final feed solution was prepared by combining the uranium solution with the required amounts of concentrated (15.7M) nitric acid and deionized water required to obtain $3500 \mathrm{~mL}$ of solution containing $8 \mathrm{M}$ nitric acid. The final composition of the feed solution for the experiment is given in Table 3 .

\section{$\underline{\text { Feed Adjustment }}$}

To ensure that all of the plutonium was present in the 4+ valence in the initial experiment, the column feed solution was treated by adding nominally $80 \mathrm{~mL}$ of a $2.9 \mathrm{M}$ solution of ferrous sulfamate $\left(\mathrm{Fe}\left(\mathrm{NH}_{2} \mathrm{SO}_{3}\right)_{2}\right)$. This amount of $\mathrm{Fe}\left(\mathrm{NH}_{2} \mathrm{SO}_{3}\right)_{2}$ was sufficient to reduce all the plutonium from higher valences $(4+, 5+$, and $6+$ ) to the $3+$ valence and establish a $0.05 \mathrm{M}$ excess. Once the addition was complete, the feed solution was heated to $50^{\circ} \mathrm{C}$ for $30 \mathrm{~min}$ to oxidize the plutonium back to the 4+ valence. After cooling, the solution was filtered to remove any solids.

Although plutonium was not added to the feed solution in the second experiment, $\mathrm{Fe}\left(\mathrm{NH}_{2} \mathrm{SO}_{3}\right)_{2}$ was added to ensure that sulfate (a decomposition product) was present in the solution at the same concentration as used in the previous experiment. Prior to column operation, $80 \mathrm{~mL}$ of 
$2.9 \mathrm{M} \mathrm{Fe}\left(\mathrm{NH}_{2} \mathrm{SO}_{3}\right)_{2}$ were added to the feed solution. The solution was then heated to $50^{\circ} \mathrm{C}$ for 30 min. After cooling, the solution was filtered to remove any solids.

\section{Column Operation}

Prior to loading the feed solutions, the Reillex HPQ ${ }^{\mathrm{TM}}$ resin was conditioned with 1.5 bed volumes $(289 \mathrm{~mL})$ of $8 \mathrm{M}$ nitric acid. The flowrate was adjusted to $19 \mathrm{~mL} / \mathrm{min}$ by timing the collection of the column effluent. The feed solution for each experiment was then loaded onto the column at $18 \mathrm{~mL} / \mathrm{min}$. A sample of the effluent was collected every bed volume (i.e. every $194 \mathrm{~mL}$ ) by collecting the last $5 \mathrm{~mL}$ of solution in a 2-dram vial previously marked at the $5 \mathrm{~mL}$ level. The loaded column was washed with nominally 20 bed volumes $(3880 \mathrm{~mL})$ of $8 \mathrm{M}$ nitric acid using a flowrate of $26 \mathrm{~mL} / \mathrm{min}$. A $5 \mathrm{~mL}$ sample of the effluent was collected every bed volume using the same procedure as described above.

The anion exchange columns were eluted with nominally 3 bed volumes $(578 \mathrm{~mL})$ of $0.35 \mathrm{M}$ nitric acid using a flowrate of $7 \mathrm{~mL} / \mathrm{min}$. In the first experiment, a displacement volume was collected until the first sign of color (characteristic of $\mathrm{Pu}^{4+}$ ) was seen in the column effluent. At this point, a hearts cut was collected until color disappeared from the effluent. After the disappearance of color, approximately 1 bed volume of solution was collected as a tails cut. In the second experiment, when plutonium was not added to the feed solution, the displacement and the hearts and tails cut were maintained at approximately the same volume as collected in the initial experiment.

\section{$\underline{\text { Solution Analysis }}$}

The samples of the column effluent taken during column loading and washing were analyzed for uranium by the Chemchek method, which is based on the fluorescence exhibited by uranium in phosphoric acid when exposed to ultraviolet light. Composite samples from the effluent generated during loading and washing were also analyzed for plutonium to measure plutonium losses during these operations. The plutonium concentrations were determined by liquid scintillation counting using a gamma pulse height analysis to correct for americium-241 activity. Samples from the displacement and the hearts and tails cuts were analyzed for both plutonium and uranium. Free acid results for the feed solution and hearts cut were obtained by titration. 


\section{This page was intentionally left blank.}




\section{Results and Discussion}

The analytical results from both anion exchange experiments are summarized in Appendix A. The measured uranium concentrations were used to construct concentration profiles for the column effluent for each experiment (see Figure 1). From Figure 1, it is evident that the uranium concentrations in the effluent streams for both experiments were almost identical during column loading. However, the effect of plutonium loading can clearly be seen during column washing. When plutonium was loaded onto the resin in experiment no. 1, fewer adsorption sites were available for uranium loading. The decreased uranium loading resulted in more rapid decrease in the uranium concentration until the feed solution was completely flushed from the column.

Maximizing the amount of uranium which loads onto the resin provides a conservative estimate of the washing requirements to achieve a desired plutonium/uranium separation. To calculate the washing requirements (i.e. number of bed volumes) to reject a specified percentage of uranium from the plutonium product, uranium material balances were performed for both experiments. For column loading and washing, where the last $5 \mathrm{~mL}$ of each bed volume were collected and analyzed, the average uranium concentration of a bed volume was calculated by averaging the concentration measured in the $5 \mathrm{~mL}$ sample with the concentration measured for the previous bed volume. The mass of uranium at each sample point was then calculated as the product of the concentration and respective volume. By summing the total mass of uranium recovered from the column effluent, the fraction of the uranium removed as a function of the number of bed volumes of solution was calculated as a percentage of the total uranium recovered. The material balance calculations are summarized in Appendix B.

The cumulative uranium recovery in the effluent stream of the anion exchange column is plotted on Figure 2 for both experiments. The effect of increased uranium loading when plutonium is not present in the feed solution (experiment no. 2) can also be seen on this figure. The end result is a slower removal of uranium from the column for the same volume of wash solution due to increased resin loading. The data from experiment no. 2 can be used to predict conservative washing requirements to achieve a desired plutonium/uranium separation. The number of bed volumes of wash solution to achieve the separation is a function of the amount of plutonium in the product stream as well as the uranium to plutonium ratio. Table 4 summarizes a series of calculations used to define the washing requirements to purify a $1 \mathrm{~kg}$ batch of plutonium for a range of uranium to plutonium ratios. Data from Figure 2 were used to predict a conservative number of bed volumes of wash solution to achieve a maximum of $0.01 \mathrm{~g}$ uranium $/ \mathrm{g}$ plutonium in the product solution.

To illustrate the relationship between the washing requirements and the uranium to plutonium ratio, data from Table 4 are plotted on Figure 3. It should be noted that the number of column bed volumes of wash solution to achieve the desired separation illustrated on the figure are based on a laboratory experiment where the holdup volume of the anion exchange system was minimal. In the HB-Line anion exchange process, piping routes between feed tanks and the columns likely contain points where a small amount of solution will accumulate. If this is the case, the washing requirements to achieve the desired plutonium purification would be higher by the volume of solution necessary to flush the feed solution from the lines upstream from the columns. 
WSRC-TR-2002-00097

Revision 0

Table 4 Washing Requirements to Purify a $1 \mathrm{~kg}$ Batch of Plutonium

\begin{tabular}{|c|c|c|c|c|c|c|}
\hline $\begin{array}{c}\text { Plutonium } \\
\text { Batch } \\
\text { Size } \\
(\mathrm{kg}) \\
\end{array}$ & $\begin{array}{l}\text { Uranium to } \\
\text { Plutonium } \\
\text { Ratio }\end{array}$ & $\begin{array}{c}\text { Total } \\
\text { Uranium } \\
\text { in Batch } \\
(\mathrm{kg})\end{array}$ & $\begin{array}{c}\text { Maximum } \\
\text { Uranium } \\
\text { in Product } \\
(\mathrm{kg})\end{array}$ & $\begin{array}{c}\text { Uranium } \\
\text { Removal } \\
\text { Required } \\
(\mathrm{kg})\end{array}$ & $\begin{array}{c}\text { Percent } \\
\text { Uranium } \\
\text { Removal } \\
(\%)\end{array}$ & $\begin{array}{l}\text { Min. Bed } \\
\text { Volumes } \\
\text { of Wash }\end{array}$ \\
\hline 1 & 0.1 & 0.1 & 0.01 & 0.09 & 90.00 & 3 \\
\hline 1 & 0.5 & 0.5 & 0.01 & 0.49 & 98.00 & 8 \\
\hline 1 & 1.0 & 1.0 & 0.01 & 0.99 & 99.00 & 10 \\
\hline 1 & 2.0 & 2.0 & 0.01 & 1.99 & 99.50 & 12 \\
\hline 1 & 3.0 & 3.0 & 0.01 & 2.99 & 99.67 & 13 \\
\hline 1 & 4.0 & 4.0 & 0.01 & 3.99 & 99.75 & 14 \\
\hline 1 & 5.0 & 5.0 & 0.01 & 4.99 & 99.80 & 15 \\
\hline
\end{tabular}




\section{Conclusions}

Two small-scale anion exchange experiments were performed using conditions representative of the HB-Line Phase II facility to measure the removal of uranium from a plutonium-containing feed as a function of the volume of wash solution. In the initial experiment, a feed solution representative of the facility containing nominally a 3:1 mass ratio of uranium to plutonium was decontaminated using nominally 20 column bed volumes of $8 \mathrm{M}$ nitric acid. In the experiment, the uranium concentration in the effluent stream was measured to follow the cumulative removal of uranium during column operations. To reduce the uranium concentration in the product stream to $\leq 0.01 \mathrm{~g}$ uranium $/ \mathrm{g}$ plutonium, a concentration which will not interfere with a subsequent loss-on-ignition test performed on $\mathrm{PuO}_{2}$ produced from the material, nominally 12 bed volumes of wash solution were required. This result was based on a $1 \mathrm{~kg}$ plutonium batch size requiring the removal of $99.67 \%$ of the uranium in the feed solution to meet the desired plutonium product purity.

Since solutions processed through the HB-Line Phase II facility could potentially contain greater uranium to plutonium mass ratios than used in the initial experiment, a second column run was performed in which an almost identical feed solution containing no plutonium was loaded onto the resin. Since the feed solution contained no plutonium, additional resin sites were available to achieve a maximum uranium loading. Maximizing the amount of uranium loaded onto the resin subsequently maximizes the volume of wash solution required to achieve a desired plutonium/uranium separation. The effect of increased uranium loading when plutonium was not present in the feed solution was clearly seen when the concentration profiles of the effluent streams and the cumulative uranium removal from the column were compared for the two experiments. However, the additional volume of wash solution required to achieve the same plutonium/uranium separation was not excessive; only 1-2 additional bed volumes were required. The data from the second experiment can be used to predict conservative washing requirements to achieve the desired plutonium purification for any uranium to plutonium mass ratio; however, it should be noted that the predicted number of bed volumes of wash solution does not take into account the potential for holdup of solution in the HB-Line piping. Additional wash solution would be required to flush any uranium from the process lines upstream from the columns. 


\section{This page was intentionally left blank.}




\section{References}

1. DOE-STD-3013-99, Stabilization, Packaging, and Storage of Plutonium-Bearing Materials, U. S. Department of Energy, Washington DC (November 1999).

2. J. J. Katz, G. T. Seaborg, and L. R. Morss, Editors, The Chemistry of the Actinide Elements, $2^{\text {nd }}$ Edition, Vol. 1, Chapman and Hall, New York, NY, p. 558, (1986).

3. E. A. Kyser III, Plutonium Loading onto Reillex $H P Q^{T M}$ Anion Exchange Resin, Report No. WSRC-TR-2000-00320, Westinghouse Savannah River Company, Aiken, SC (September 2000).

4. J. Korkisch, Handbook of Ion Exchange Resins: Their Applications to Inorganic Analytical Chemistry, Vol. II, CRC Press, Inc, Boca Raton, FL, pp. 18 and 22 (1989). 


\section{This page was intentionally left blank.}


Figure 1 Uranium Concentration in Effluent Streams During Anion Exchange Column Operation

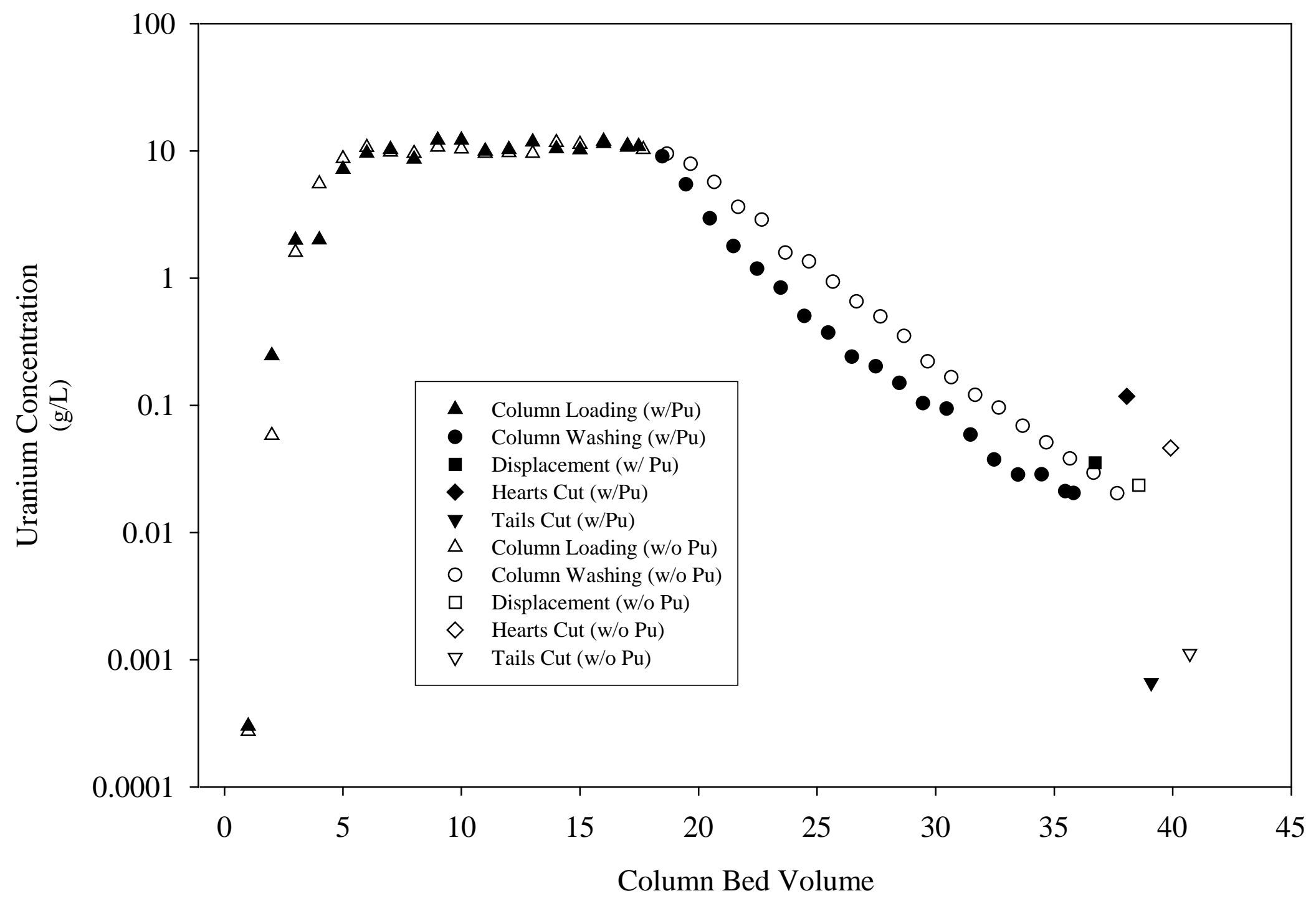




\section{This page was intentionally left blank.}


Figure 2 Cumulative Recovery of Uranium in Effluent Streams During Anion Exchange Column Operation

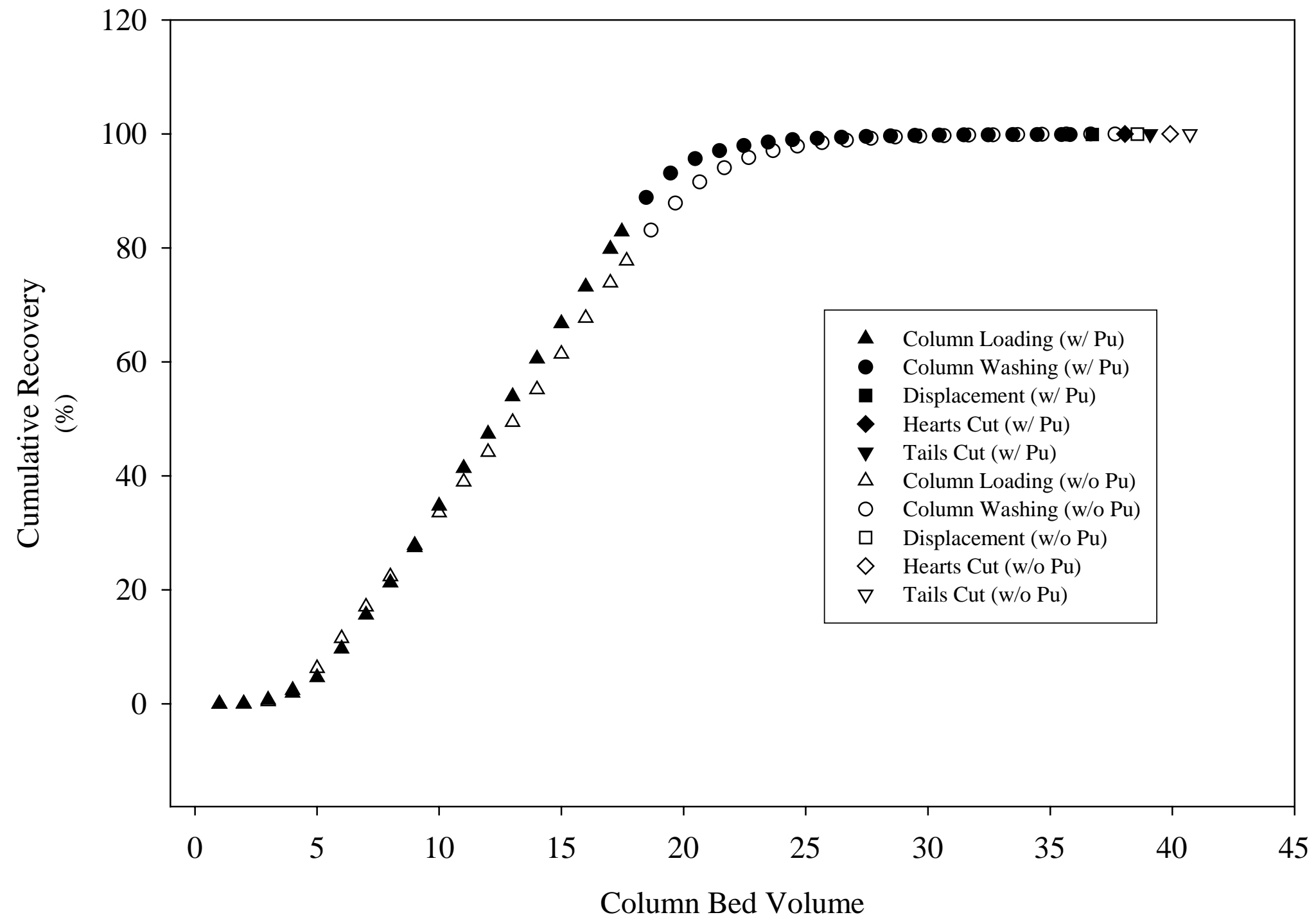




\section{This page was intentionally left blank.}


Figure 3 Estimated Washing Requirements to Achieve $\leq 0.01 \mathrm{~g}$ Uranium/g Plutonium in Column Product Stream

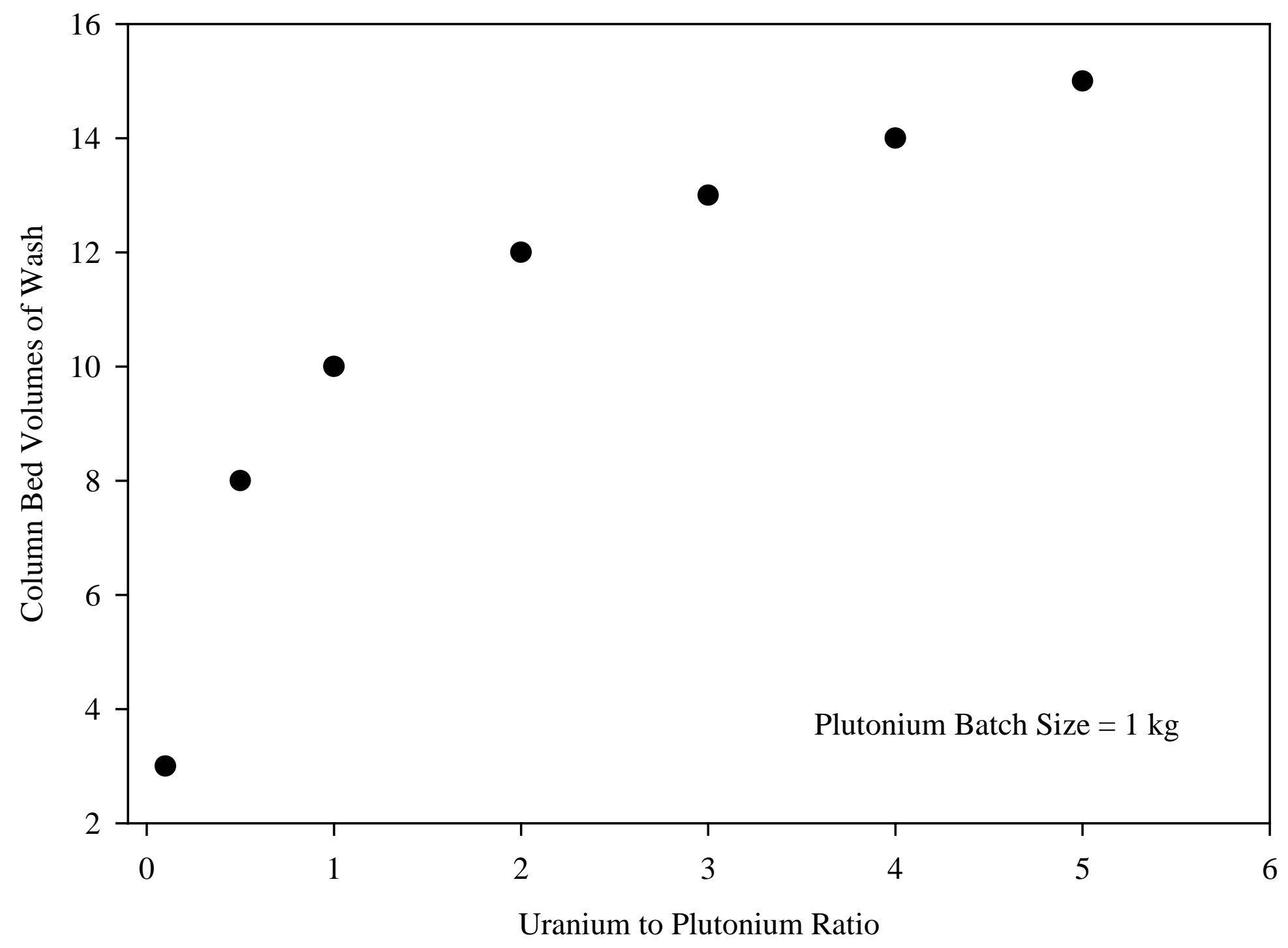




\section{This page was intentionally left blank.}




\section{Appendix A Analytical Results from Anion Exchange Experiments}

The analytical results for the two anion exchange experiments are summarized in Tables A.1 and A.2. The data include uranium analyses for the individual samples taken during column loading and washing, and plutonium and uranium analyses for samples taken from the feed solution and volumes collected during column elution. Free acid results were obtained for the feed solution and plutonium product for experiment no. 1. Volumes of the solutions from which samples were removed are listed for the feed solution and volumes collected during column elution. For experiment no. 1, a composite sample of the column effluent (not collected as a $5 \mathrm{~mL}$ sample) was analyzed for plutonium (and uranium) to measure column losses.

Table A.1 Analytical Results from Anion Exchange Experiment No. 1

\begin{tabular}{lcccc}
\hline \hline Sample & $\begin{array}{c}\text { Volume } \\
(\mathrm{mL})\end{array}$ & $\begin{array}{c}\text { Free Acid } \\
(\mathrm{M})\end{array}$ & $\begin{array}{c}\text { Uranium } \\
(\mathrm{g} / \mathrm{L})\end{array}$ & $\begin{array}{c}\text { Plutonium } \\
(\mathrm{g} / \mathrm{L})\end{array}$ \\
\hline Feed & 3389 & 7.68 & 10.4 & 2.76 \\
Feed & 3389 & 7.66 & 10.4 & 2.81 \\
Feed & 3389 & 7.38 & 8.80 & 2.76 \\
Load BV-1 & & & 0.00030 & \\
Load BV-2 & & & 0.25 & \\
Load BV-3 & & & 2.00 & \\
Load BV-4 & & & 2.01 & \\
Load BV-5 & & & 7.17 & \\
Load BV-6 & & & 9.62 & \\
Load BV-7 & & & 10.3 & \\
Load BV-8 & & & 8.64 & \\
Load BV-9 & & & 12.2 & \\
Load BV-10 & & & 12.2 & \\
Load BV-11 & & & 9.97 & \\
Load BV-12 & & & 10.3 & \\
Load BV-13 & & & 11.8 & \\
Load BV-14 & & & 10.5 & \\
Load BV-15 & & & 10.2 & \\
Load BV-16 & & & 11.5 & \\
Load BV-17 & & & 10.7 & \\
Load BV-18 & & & 10.9 & \\
Composite EC & 3299 & & 7.48 & 0.0025 \\
Wash BV-1 & & & 9.03 & \\
Wash BV-2 & & & 5.46 & \\
Wash BV-3 & & & 2.95 & \\
Wash BV-4 & & & 1.78 & \\
Wash BV-5 & & & 0.19 & \\
Wash BV-6 & & & 0.50 & \\
Wash BV-7 & & & 0.37 & \\
Wash BV-8 & & & 0.24 & \\
Wash BV-9 & & & & \\
\hline
\end{tabular}


Table A.1 Continued

\begin{tabular}{lcccc}
\hline \hline Sample & $\begin{array}{c}\text { Volume } \\
(\mathrm{mL})\end{array}$ & $\begin{array}{c}\text { Free Acid } \\
(\mathrm{M})\end{array}$ & $\begin{array}{c}\text { Uranium } \\
(\mathrm{g} / \mathrm{L})\end{array}$ & $\begin{array}{c}\text { Plutonium } \\
(\mathrm{g} / \mathrm{L})\end{array}$ \\
\hline Wash BV-10 & & & 0.20 & \\
Wash BV-11 & & & 0.15 & \\
Wash BV-12 & & & 0.10 & \\
Wash BV-13 & & & 0.094 & \\
Wash BV-14 & & & 0.059 & \\
Wash BV-15 & & 0.037 & \\
Wash BV-16 & & 0.028 & \\
Wash BV-17 & & & 0.029 & \\
Wash BV-18 & & 0.021 & \\
Wash BV-19 & & 0.020 & \\
Composite WC & 3464 & & 0.11 & 0.0076 \\
Displacement & 176 & & 0.035 & 0.085 \\
Hearts Cut & 260 & 0.48 & 0.12 & 37.6 \\
Tails Cut & 200 & & 0.00066 & 0.059 \\
\hline
\end{tabular}

Table A.2 Analytical Results from Anion Exchange Experiment No. 2

\begin{tabular}{lcc}
\hline \hline Sample & $\begin{array}{c}\text { Volume } \\
(\mathrm{mL})\end{array}$ & $\begin{array}{c}\text { Uranium } \\
(\mathrm{g} / \mathrm{L})\end{array}$ \\
\hline Feed & 3427 & 10.7 \\
Feed & 3427 & 11.8 \\
Feed & 3427 & 11.7 \\
Load BV-1 & & 0.00028 \\
Load BV-2 & & 0.058 \\
Load BV-3 & & 1.60 \\
Load BV-4 & & 5.54 \\
Load BV-5 & & 8.72 \\
Load BV-6 & & 10.7 \\
Load BV-7 & & 9.82 \\
Load BV-8 & & 9.58 \\
Load BV-9 & & 10.8 \\
Load BV-10 & & 10.4 \\
Load BV-11 & & 9.58 \\
Load BV-12 & & 9.71 \\
Load BV-13 & & 9.56 \\
Load BV-14 & & 11.7 \\
Load BV-15 & & 11.3 \\
Load BV-16 & & 11.9 \\
Load BV-17 & & 11.1 \\
Load BV-18 & & 10.3 \\
\hline
\end{tabular}


Table A. 2 Continued

\begin{tabular}{lcc}
\hline \hline Sample & $\begin{array}{c}\text { Volume } \\
(\mathrm{mL})\end{array}$ & $\begin{array}{c}\text { Uranium } \\
(\mathrm{g} / \mathrm{L})\end{array}$ \\
\hline Wash BV-1 & & 9.52 \\
Wash BV-2 & & 7.92 \\
Wash BV-3 & & 5.69 \\
Wash BV-4 & & 3.63 \\
Wash BV-5 & & 2.88 \\
Wash BV-6 & & 1.59 \\
Wash BV-7 & & 1.35 \\
Wash BV-8 & & 0.94 \\
Wash BV-9 & & 0.65 \\
Wash BV-10 & & 0.50 \\
Wash BV-11 & & 0.35 \\
Wash BV-12 & & 0.22 \\
Wash BV-13 & & 0.17 \\
Wash BV-14 & & 0.12 \\
Wash BV-15 & & 0.096 \\
Wash BV-16 & & 0.069 \\
Wash BV-17 & & 0.051 \\
Wash BV-18 & & 0.038 \\
Wash BV-19 & & 0.030 \\
Wash BV-20 & & 0.020 \\
Displacement & 176 & 0.024 \\
Hearts Cut & 261 & 0.046 \\
Tails Cut & 156 & 0.0011 \\
\hline
\end{tabular}




\section{This page was intentionally left blank.}




\section{Appendix B Material Balances for Anion Exchange Experiments}

The uranium material balance calculations for the two anion exchange experiments are summarized in Tables B.1 and B.2. For each bed volume of effluent solution during column loading and washing and the volumes collected during column elution, the uranium concentration, average uranium concentration (as appropriate), measured volume, recovered uranium mass, relative uranium recovery, and cumulative uranium recovery are given. The uranium concentrations listed in Tables B.1 and B.2 are the raw data obtained for each sample. The number of significant figures for the uranium concentration was not adjusted to minimize the display of rounding error in the calculations.

Table B.1 Uranium Material Balance for Anion Exchange Experiment No. 1

\begin{tabular}{|c|c|c|c|c|c|c|}
\hline $\begin{array}{c}\text { Bed } \\
\text { Volume }\end{array}$ & $\begin{array}{l}\text { Uranium } \\
\text { Conc. } \\
\text { (mg/L) }\end{array}$ & $\begin{array}{l}\text { Average } \\
\text { Uranium } \\
\text { Conc. } \\
\text { (mg/L) }\end{array}$ & $\begin{array}{l}\text { Measured } \\
\text { Volume } \\
(\mathrm{L}) \\
\end{array}$ & $\begin{array}{l}\text { Total } \\
\text { Uranium } \\
\text { Mass } \\
(\mathrm{mg})\end{array}$ & $\begin{array}{c}\text { Relative } \\
\text { Uranium } \\
\text { Recovery } \\
(\%)\end{array}$ & $\begin{array}{c}\text { Cumulative } \\
\text { Uranium } \\
\text { Recovery } \\
(\%)\end{array}$ \\
\hline 1 & 0.3015 & 0 & 0.194 & 0 & 0.00 & 0.00 \\
\hline 2 & 247 & 124 & 0.194 & 24 & 0.07 & 0.07 \\
\hline 3 & 1996.5 & 1122 & 0.194 & 218 & 0.67 & 0.74 \\
\hline 4 & 2005 & 2001 & 0.194 & 388 & 1.19 & 1.94 \\
\hline 5 & 7165 & 4585 & 0.194 & 889 & 2.74 & 4.68 \\
\hline 6 & 9620 & 8393 & 0.194 & 1628 & 5.01 & 9.69 \\
\hline 7 & 10300 & 9960 & 0.194 & 1932 & 5.95 & 15.63 \\
\hline 8 & 8640 & 9470 & 0.194 & 1837 & 5.65 & 21.29 \\
\hline 9 & 12150 & 10395 & 0.194 & 2017 & 6.21 & 27.49 \\
\hline 10 & 12150 & 12150 & 0.194 & 2357 & 7.25 & 34.75 \\
\hline 11 & 9970 & 11060 & 0.194 & 2146 & 6.60 & 41.35 \\
\hline 12 & 10270 & 10120 & 0.194 & 1963 & 6.04 & 47.39 \\
\hline 13 & 11750 & 11010 & 0.194 & 2136 & 6.57 & 53.96 \\
\hline 14 & 10450 & 11100 & 0.194 & 2153 & 6.63 & 60.59 \\
\hline 15 & 10200 & 10325 & 0.194 & 2003 & 6.16 & 66.76 \\
\hline 16 & 11450 & 10825 & 0.194 & 2100 & 6.46 & 73.22 \\
\hline 17 & 10700 & 11075 & 0.194 & 2149 & 6.61 & 79.83 \\
\hline 17.5 & 10900 & 10800 & 0.091 & 983 & 3.02 & 82.85 \\
\hline 18.5 & 9030 & 9965 & 0.194 & 1933 & 5.95 & 88.80 \\
\hline 19.5 & 5455 & 7243 & 0.194 & 1405 & 4.32 & 93.13 \\
\hline 20.5 & 2950 & 4203 & 0.194 & 815 & 2.51 & 95.64 \\
\hline 21.5 & 1780 & 2365 & 0.194 & 459 & 1.41 & 97.05 \\
\hline 22.5 & 1185 & 1483 & 0.194 & 288 & 0.89 & 97.93 \\
\hline 23.5 & 839.5 & 1012 & 0.194 & 196 & 0.60 & 98.54 \\
\hline 24.5 & 503.5 & 672 & 0.194 & 130 & 0.40 & 98.94 \\
\hline 25.5 & 373 & 438 & 0.194 & 85 & 0.26 & 99.20 \\
\hline 26.5 & 240.5 & 307 & 0.194 & 60 & 0.18 & 99.38 \\
\hline 27.5 & 202 & 221 & 0.194 & 43 & 0.13 & 99.52 \\
\hline 28.5 & 150 & 176 & 0.194 & 34 & 0.11 & 99.62 \\
\hline
\end{tabular}


Table B.1 Continued

\begin{tabular}{ccccccc}
\hline \hline $\begin{array}{c}\text { Bed } \\
\text { Volume }\end{array}$ & $\begin{array}{c}\text { Uranium } \\
\text { Conc. }\end{array}$ & $\begin{array}{c}\text { Average } \\
\text { Uranium } \\
\text { Conc. } \\
(\mathrm{mg} / \mathrm{L})\end{array}$ & $\begin{array}{c}\text { Measured } \\
\text { Volume }\end{array}$ & $\begin{array}{c}\text { Total } \\
\text { Uranium } \\
\text { Mass } \\
(\mathrm{mg})\end{array}$ & $\begin{array}{c}\text { Relative } \\
\text { Uranium } \\
\text { Recovery } \\
(\%)\end{array}$ & $\begin{array}{c}\text { Cumulative } \\
\text { Uranium } \\
\text { Recovery } \\
(\%)\end{array}$ \\
\hline 29.5 & 104 & 127 & 0.194 & 25 & 0.08 & 99.70 \\
30.5 & 94.15 & 99 & 0.194 & 19 & 0.06 & 99.76 \\
31.5 & 58.7 & 76 & 0.194 & 15 & 0.05 & 99.80 \\
32.5 & 37.4 & 48 & 0.194 & 9 & 0.03 & 99.83 \\
33.5 & 28.45 & 33 & 0.194 & 6 & 0.02 & 99.85 \\
34.5 & 28.65 & 29 & 0.194 & 6 & 0.02 & 99.87 \\
35.5 & 21.1 & 25 & 0.194 & 5 & 0.01 & 99.88 \\
35.8 & 20.4 & 21 & 0.067 & 1 & 0.00 & 99.89 \\
36.7 & 35.4 & N/A & 0.176 & 6 & 0.02 & 99.91 \\
38.1 & 117.5 & N/A & 0.260 & 31 & 0.09 & 100.00 \\
39.1 & 0.66 & N/A & 0.200 & 0 & 0.00 & 100.00 \\
Total & & & & 32494 & 100.00 & \\
\hline N/A & & & & & & \\
\hline
\end{tabular}

N/A (Composite Samples from Column Elution)

Table B.2 Material Balance for Anion Exchange Experiment No. 2

\begin{tabular}{ccccccc}
\hline \hline $\begin{array}{c}\text { Bed } \\
\text { Volume }\end{array}$ & $\begin{array}{c}\text { Uranium } \\
\text { Conc. }\end{array}$ & $\begin{array}{c}\text { Average } \\
\text { Uranium } \\
\text { Conc. } \\
(\mathrm{mg} / \mathrm{L})\end{array}$ & $\begin{array}{c}\text { Measured } \\
\text { Volume }\end{array}$ & $\begin{array}{c}\text { Total } \\
\text { Uranium } \\
\text { Mass } \\
(\mathrm{mg})\end{array}$ & $\begin{array}{c}\text { Relative } \\
\text { Uranium } \\
\text { Recovery } \\
(\%)\end{array}$ & $\begin{array}{c}\text { Cumulative } \\
\text { Uranium } \\
\text { Recovery } \\
(\%)\end{array}$ \\
\hline 1 & 0.275 & 0 & 0.194 & 0 & 0.00 & 0.00 \\
2 & 58.05 & 29 & 0.194 & 6 & 0.02 & 0.02 \\
3 & 1600 & 829 & 0.194 & 161 & 0.45 & 0.47 \\
4 & 5540 & 3570 & 0.194 & 693 & 1.94 & 2.40 \\
5 & 8715 & 7128 & 0.194 & 1383 & 3.87 & 6.27 \\
6 & 10650 & 9683 & 0.194 & 1878 & 5.25 & 11.52 \\
7 & 9820 & 10235 & 0.194 & 1986 & 5.55 & 17.08 \\
8 & 9575 & 9698 & 0.194 & 1881 & 5.26 & 22.34 \\
9 & 10750 & 10163 & 0.194 & 1972 & 5.51 & 27.85 \\
10 & 10350 & 10550 & 0.194 & 2047 & 5.72 & 33.58 \\
11 & 9575 & 9963 & 0.194 & 1933 & 5.41 & 38.98 \\
12 & 9705 & 9640 & 0.194 & 1870 & 5.23 & 44.21 \\
13 & 9555 & 9630 & 0.194 & 1868 & 5.22 & 49.44 \\
14 & 11650 & 10603 & 0.194 & 2057 & 5.75 & 55.19 \\
15 & 11250 & 11450 & 0.194 & 2221 & 6.21 & 61.40 \\
16 & 11900 & 11575 & 0.194 & 2246 & 6.28 & 67.68 \\
17 & 11050 & 11475 & 0.194 & 2226 & 6.23 & 73.91 \\
17.7 & 10250 & 10650 & 0.129 & 1374 & 3.84 & 77.75 \\
\hline
\end{tabular}


WSRC-TR-2002-00097

Revision 0

Table B.2 Continued

\begin{tabular}{ccccccc}
\hline \hline $\begin{array}{c}\text { Bed } \\
\text { Volume }\end{array}$ & $\begin{array}{c}\text { Uranium } \\
\text { Conc. }\end{array}$ & $\begin{array}{c}\text { Average } \\
\text { Uranium } \\
\text { Conc. } \\
(\mathrm{mg} / \mathrm{L})\end{array}$ & $\begin{array}{c}\text { Measured } \\
\text { Volume }\end{array}$ & $\begin{array}{c}\text { Total } \\
\text { Uranium } \\
\text { Mass } \\
(\mathrm{mg})\end{array}$ & $\begin{array}{c}\text { Relative } \\
\text { Uranium } \\
\text { Recovery } \\
(\%)\end{array}$ & $\begin{array}{c}\text { Cumulative } \\
\text { Uranium } \\
\text { Recovery } \\
(\%)\end{array}$ \\
\hline 18.7 & 9515 & 9883 & 0.194 & 1917 & 5.36 & 83.11 \\
19.7 & 7915 & 8715 & 0.194 & 1691 & 4.73 & 87.84 \\
20.7 & 5685 & 6800 & 0.194 & 1319 & 3.69 & 91.53 \\
21.7 & 3630 & 4658 & 0.194 & 904 & 2.53 & 94.06 \\
22.7 & 2880 & 3255 & 0.194 & 631 & 1.77 & 95.82 \\
23.7 & 1585 & 2233 & 0.194 & 433 & 1.21 & 97.03 \\
24.7 & 1350 & 1468 & 0.194 & 285 & 0.80 & 97.83 \\
25.7 & 936 & 1143 & 0.194 & 222 & 0.62 & 98.45 \\
26.7 & 654 & 795 & 0.194 & 154 & 0.43 & 98.88 \\
27.7 & 498 & 576 & 0.194 & 112 & 0.31 & 99.19 \\
28.7 & 351 & 425 & 0.194 & 82 & 0.23 & 99.42 \\
29.7 & 221.5 & 286 & 0.194 & 56 & 0.16 & 99.58 \\
30.7 & 166 & 194 & 0.194 & 38 & 0.11 & 99.68 \\
31.7 & 120.5 & 143 & 0.194 & 28 & 0.08 & 99.76 \\
32.7 & 95.7 & 108 & 0.194 & 21 & 0.06 & 99.82 \\
33.7 & 69 & 82 & 0.194 & 16 & 0.04 & 99.87 \\
34.7 & 51.25 & 60 & 0.194 & 12 & 0.03 & 99.90 \\
35.7 & 38.2 & 45 & 0.194 & 9 & 0.02 & 99.92 \\
36.7 & 29.55 & 34 & 0.194 & 7 & 0.02 & 99.94 \\
37.7 & 20.35 & 25 & 0.194 & 5 & 0.01 & 99.95 \\
38.6 & 23.6 & N/A & 0.176 & 4 & 0.01 & 99.97 \\
39.9 & 46.25 & N/A & 0.261 & 12 & 0.03 & 100.00 \\
40.7 & 1.12 & N/A & 0.156 & 0 & 0.00 & 100.00 \\
& & & & & & \\
Total & & & & 35760 & 100.00 & \\
\hline N/A & & & & & &
\end{tabular}

N/A (Composite Samples from Column Elution)

By comparing the total mass of uranium recovered from the column effluent to the total amount of uranium in the feed solution, material balance closures can be calculated for each anion exchange experiment. The calculations are summarized in Table B.3. The material balance closure was defined as the ratio of the mass of uranium recovered in the column effluent to the mass of uranium in the feed solution. 
WSRC-TR-2002-00097

Revision 0

Table B.3 Material Balance Closure for Anion Exchange Experiments

\begin{tabular}{ccccc}
\hline \hline $\begin{array}{c}\text { Experiment } \\
\text { No. }\end{array}$ & $\begin{array}{c}\text { Average } \\
\text { Uranium } \\
\text { Concentration } \\
(\mathrm{mg} / \mathrm{L})\end{array}$ & $\begin{array}{c}\text { Feed Solution Data } \\
\text { Volume }\end{array}$ & $\begin{array}{c}\text { Uranium } \\
\text { Mass }\end{array}$ & $\begin{array}{c}\text { Material } \\
\text { Balance } \\
\text { Closure }\end{array}$ \\
& 9865 & $(\mathrm{~mL})$ & $(\mathrm{mg})$ & $(\%)$ \\
\hline 1 & 11350 & 3389 & 33432 & 97 \\
2 & 3427 & 38896 & 92 \\
\hline
\end{tabular}

The uranium material balance closures for the two anion exchange experiments were reasonably good based on the variation in the uranium analyses which was seen. Three samples of the feed solution were analyzed for each experiment. The relative standard deviation of the average concentration for the two experiments ranged from 5-10\%. This variation can be used to show that the material balance closures in Table B.3 are not statistically different from $100 \%$.

The plutonium material balance for experiment no. 1 is summarized in Table B.4. The table provides the concentration, volume, mass, and percent recovery for the effluent stream during each column operation. The concentrations of the composite samples of the column effluent collected during loading and washing were assumed to be same as the concentration which would have been measured if the $5 \mathrm{~mL}$ samples had not been removed.

Table B.4 Plutonium Material Balance for Anion Exchange Experiment No. 1

\begin{tabular}{lcccc}
\hline \hline $\begin{array}{c}\text { Column } \\
\text { Operation }\end{array}$ & $\begin{array}{c}\text { Plutonium } \\
\text { Concentration } \\
(\mathrm{g} / \mathrm{L})\end{array}$ & $\begin{array}{c}\text { Total } \\
\text { Volume } \\
(\mathrm{mL})\end{array}$ & $\begin{array}{c}\text { Plutonium } \\
\text { Mass } \\
(\mathrm{g})\end{array}$ & $\begin{array}{c}\text { Percent } \\
\text { Recovery } \\
(\%)\end{array}$ \\
\hline Loading & $0.00_{2}$ & 3389 & 0.01 & 0.1 \\
Washing & $0.00_{8}$ & 3559 & 0.03 & 0.3 \\
Displacement & $0.08_{5}$ & 176 & 0.01 & 0.2 \\
Hearts Cut & 37.64 & 260 & 9.79 & 99.4 \\
Tails Cut & $0.05_{9}$ & 200 & 0.01 & 0.1 \\
& & & & \\
Total & & & 9.85 & 100.0 \\
\hline
\end{tabular}

The average plutonium concentration in the feed solution was $2.78 \mathrm{~g} / \mathrm{L}$. The volume was $3389 \mathrm{~mL}$ based on the number of bed volumes collected during column loading. Based on these values, a total of $9.40 \mathrm{~g}$ of plutonium were fed to the column. Therefore, the material balance closure was $105 \%$. Recovering slightly more plutonium than was measured in the feed solution is not unreasonable given the nominal 5\% accuracy of the analytical results and the potential for volume measurement errors during the sampling procedure. 